\section{Community Genetics}

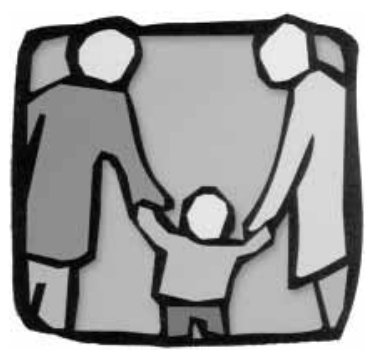

\title{
From DNA to the Community
}

\author{
Conference on Community Genetics \\ Jonquière, Québec, Canada, June 20-22, 2000 \\ Holiday Inn Convention Centre \\ 2665, Boulevard du Royaume \\ Jonquière, Québec, G7S 5B8, Canada
}

Conference hosted by

The Corporation for Research and Action on Hereditary Diseases (CORAMH) and Health Canada
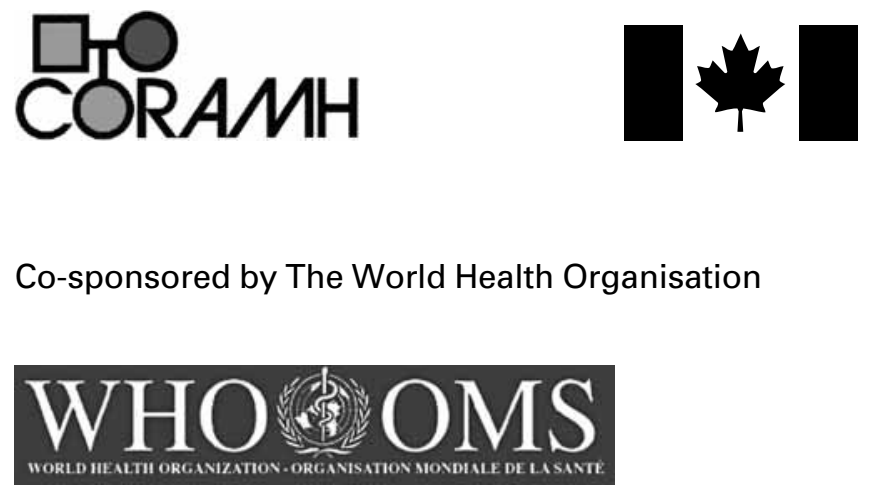

With the support of

The Fonds de la recherche en santé du Québec (FRSQ)

The Réseau de médecine génétique appliquée (RMGA)
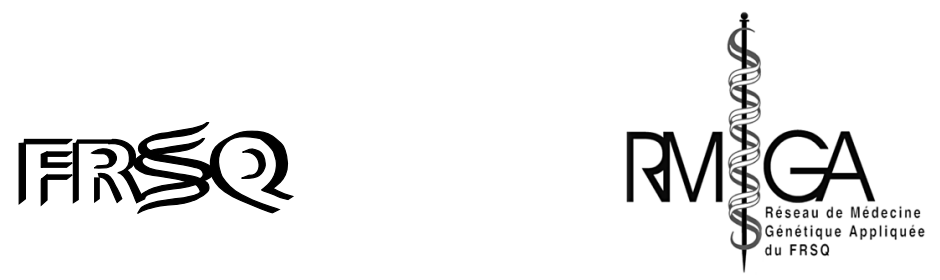

\section{KARGER \\ Fax +41613061234 \\ E-Mail karger@karger.ch}

www.karger.com
(C) 2000 S. Karger AG, Basel

1422-2795/00/0024-0137\$17.50/0

Accessible online at:

www. karger.com/journals/cmg
Daniel Gaudet, MD, PhD

Organizing Committee Chairman, CORAMH Chairman of the Board

The Corporation for Research and Action on Hereditary Diseases

Jonquière, Québec (Canada)

Tel. +1 418541 1077, Fax +1 418541 1116, E-Mail dgaudet@saglac.qc.ca 